\title{
The Objectives of Informal Workers in Denpasar City to Become Participants of BPJS Ketenagakerjaan
}

\author{
I Gusti Ayu Dyah Puspita Wardhani ${ }^{1 *}$ Ni Wayan Sri Suprapti ${ }^{2}$ I Putu Gde Sukaatmadja ${ }^{3}$ \\ 1. Faculty of Economics and Business, Udayana University, Bali, Indonesia \\ 2. Faculty of Economics and Business, Udayana University, Bali, Indonesia \\ 3. Faculty of Economics and Business, Udayana University, Bali, Indonesia
}

\begin{abstract}
This study aims to determine the role of product knowledge and subjective norms in influencing the brush and intention of informal workers to become BPJS Ketenagakerjaan participants in Denpasar City. The research sample was 188 respondents, taken using Purposive Sampling techniques, with the criteria of respondents namely informal sector workers, especially those who worked as traders, fishermen, laborers, and transportation services, who were in Denpasar City. Data is processed using Partial Least Square (PLS) analysis techniques with the help of SmartPLS 3. The results of the study show that (1) Product knowledge has a positive and significant effect on the attitude of informal workers, (2) Product knowledge has a positive and significant effect on the intention to become BPJS Ketenagakerjaan participants, (3) Attitudes have a positive and significant effect on the intention to be a participant, and (4) Subjective norms have a positive and significant effect on the intention to become a participant.
\end{abstract}

Keywords: product knowledge, subjective norms, attitude of informal workers, and intentions of informal workers

DOI: $10.7176 / \mathrm{EJBM} / 11-3-25$

\section{Introduction}

Urbanization is one factor that causes high population density. The high flow of urbanization to Bali, especially to Denpasar is influenced by factors of customs and culture and a good level of security. The urbanization consists of various ethnicities and religions with various interests with the aim of getting a better life. The level of urbanization of the population is increasingly high and can even be said to have exceeded the capacity of carrying capacity in the area they are heading to (Enter, 2010).

Denpasar was used as the location of the study to find out the intentions of BPU Workers to become participants in the BPJS Ketenagakerjaan. Denpasar is a city of the Province of Bali and has a high population density. Denpasar City's population growth per year reaches four percent. The population of Denpasar has reached 788,000 more people, with a population density of 5,600 per square kilometer. This shows a high density level (Asmara, 2014). Nearly 35\% of the population is in Denpasar City and $65 \%$ is spread in 8 regencies in Bali Province. This high population density level gives a high percentage of BPU Workers in Denpasar City

Previous research on determining the intention of a consumer to buy a product is determined by several variables. Like Zhu's (2004) study, when consumers choose a product, they usually use their understanding of the product to conduct an evaluation. This evaluation affects the processes, attitudes and quantity of consumers in information seeking. Different levels of knowledge can determine consumer purchasing decisions and indirectly affect their purchase intentions. Zhang (2007) in his research found that a decisive attitude in determining decision choices. Attitudes in decision making are influenced by variables related to the intention of the product purchased. Whereas Budiman and Wijaya (2014) stated that buying intention was influenced by high and low subjective norms, consumers with low subjective norm influences had low buying intention while high subjective norm influences had high buying intention.

\section{Literature Review}

This research model adopts the basic concept of TRA (Theory of Reasoned Action) which states that intention to behave (Intention to Behavior) is very dependent on attitude (attitude) and subjective norms of behavior. The basic concept of TRA was then modified by combining the research model that was replicated from the research of Wang et al. (2013), where one of them examined the direct effect of product knowledge variables on attitudes and intentions. Based on this, this study has four variables consisting of two dependent variables, namely the 
attitude to become a participant BPJS Ketenagakerjaan (Y1) and the intention to become a BPJS Ketenagakerjaan (Y2) participant, as well as an independent variable consisting of two variables, namely BPJS Ketenagakerjaan product knowledge (X1), and subjective norms (X2), so that the conceptual framework can be arranged as follows:

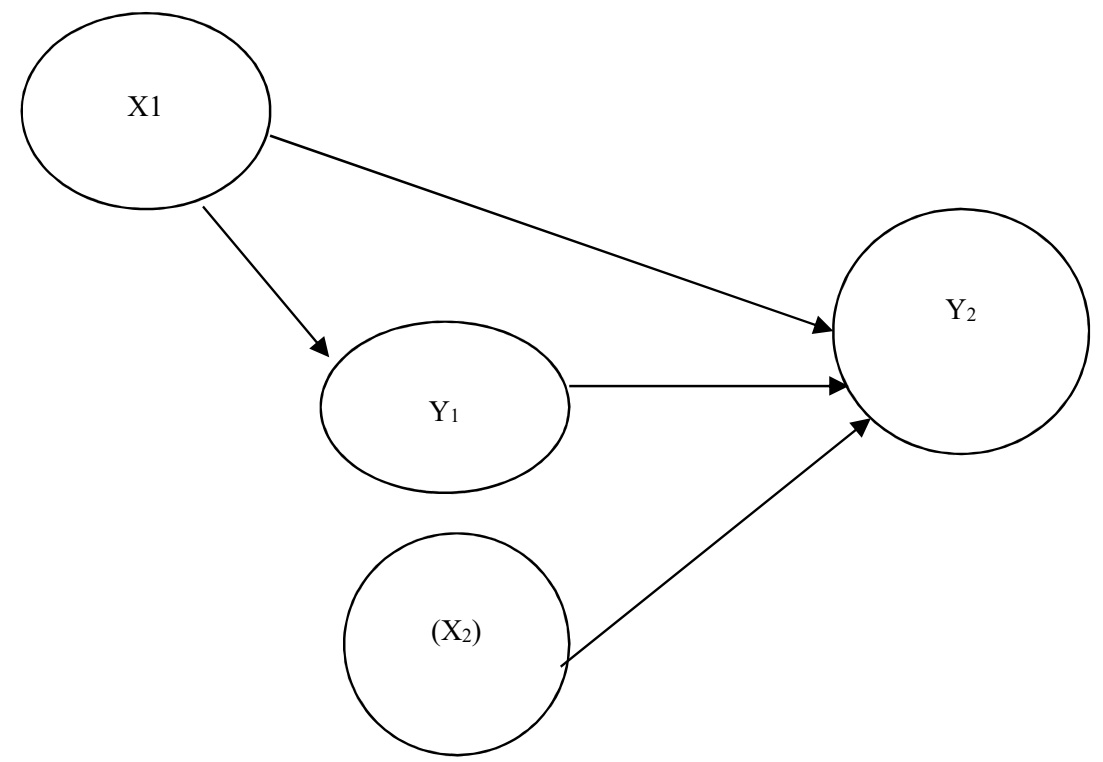

Figure 1. Framework

\subsection{Applications of HMS}

Attitudes are influenced significantly and positively by subjective knowledge. Haryanto (2014) who examined the effect of ecological knowledge and product attributes (functional and emotional attributes) on attitudes and intentions to buy products, found that attitudes toward green products were positively influenced by ecological knowledge. Ong et al. (2014) in their study found that knowledge of food and health, and knowledge of product efficacy had a significant positive impact on attitudes toward functional foods, which in turn affected the frequency of purchases.

H1: Product knowledge has a significant positive effect on the attitude of informal workers to BPJS Ketenagakerjaan

Knowledge of consumer products will distinguish simple and complex information to determine purchase intentions. Lin and Chen (2006) in their study also found that product knowledge significantly affected consumer buying intentions. Haryanto (2013) in his research on environmentally friendly products found that the intention to buy products can be increased through the development of a positive attitude towards the product. While a positive attitude is enhanced through increasing stimulus that can increase knowledge about the product.

H2: Product knowledge has a significant positive effect on the intention of informal workers to become BPJS Ketenagakerjaan participants

Coleman et al. (2011) about the intention to purchase environmentally friendly products stating that attitude in the form of initiative and commitment influences intention in purchasing products and convenience for consumers is very important. Velasquez (2012) found that the accessibility of a product affects attitudes that influence purchase intention. The attitude of a consumer about the market is a significant extension of TRA. Den's brand reputation also influences purchasing behavior (Chu et al., 2005).

H3: Attitudes have a significant positive effect on the intention of informal workers to become participants in the BPJS Ketenagakerjaan

The influence of subjective norms can come from groups of people around consumers, both family and friends. Engle et al. (2010) in his research in 12 countries showed that all countries stated that subjective norms were predictors for determining purchase intentions. Consumers will learn a lot from the behavior of others including friends, friends, groups and families. They have the ability to influence through encouragement and support to 
consumers who think their opinions are important.

H4: Subjective norms have a significant positive effect on the intention of informal workers to become participants in the BPJS Ketenagakerjaan

\section{Methods}

This study took place in Denpasar City due to economic developments in the last three years and the population density at this location. The population of Denpasar has reached 788,000 more people, with a population density of 5,600 per square kilometer. This shows a high level of population density (Asmara, 2014). Nearly $35 \%$ of the population is in Denpasar City and $65 \%$ is spread in 8 regencies in Bali Province. This high level of population density provides a high percentage of informal workers in the city of Denpasar. In addition, Denpasar is a region with a lot of employment, so it is easier to find informal sector workers who were sampled in this study. The sample is focused on informal sector workers who work as traders, fishermen, laborers, and transportation services. Because the informal sector workforce with this type of work is enough to describe the informal sector workforce in Denpasar. The population of this study is focused on informal workers in the work area of the BPJS Ketenagakerjaan Office in Bali, Denpasar City.

The research variables along with their respective indicators are presented in Table 1. The sample is 188 informal workers, consisting of workers. To test the hypothesis and produce a model that is fit (fit), the data is processed using Partial Least Square (PLS). The structural model or inner model is evaluated by looking at the percentage of variance described, namely by looking at R2 (R-square exogenous variables) for the latent dependent construct using the Stone-Geisser Q Square test and seeing the magnitude of the structural path coefficient. These estimates and stability are evaluated using the statistical t-test obtained through the bootstrapping procedure.

\section{Result}

Partial Least Square (PLS) shows all indicator values can form variables. All indicators of product knowledge variables have a value greater than 0.5 , from all indicators of variable knowledge of product indicator places to obtain products (X1.6) has the highest value of loading factor which is equal to 0.880 . For subjective norm variables, all indicators show values above 0.5 , from all indicators of subjective norm variables, indicators of friend opinion (X2.2) have the highest value of loading factor which is equal to 0.901 .

Goodness of fit structural models on the inner model are tested using values predictive - relevance $(\mathrm{Q} 2)$.

$\mathrm{Q}^{2}=1-\left(1-\mathrm{R}_{1}^{2}\right)\left(1-\mathrm{R}_{2}^{2}\right)$

$\mathrm{Q}^{2}=1$ - (1- 0,582) $(1-0,709)$

$\mathrm{Q}^{2}=1-(0,418)(0,291)$

$\mathrm{Q}^{2}=0,8784$

The above results show predictive - relevance value of 0.8784 , this value is $>0$. So that it can be interpreted that $87.84 \%$ of the variation in the outgoing intense variables is explained by the variables used in the model. The remaining $12.16 \%$ is explained by other factors outside the model. With this result, it can be concluded that this model has relevant predictive values.

\subsection{Product Knowledge on the Attitudes of Informal Workers}

Product knowledge has a positive and significant effect on the attitude of informal workers to become participants in the BPJS Ketenagakerjaan accepted. That is, the higher the knowledge of BPJS Ketenagakerjaan products by informal workers, the better the attitude of informal workers to BPJS Ketenagakerjaan, and vice versa.

The highest outer loading value of the product knowledge variable is indicated by the place indicator to obtain the product with a value of 0.880 . This shows that the higher the level of knowledge about the place to obtain BPJS Ketenagakerjaan products will influence the attitude of informal workers who are increasingly positive towards BPJS Ketenagakerjaan.

This result is in accordance with the research conducted by Kusuma and Untarini (2014) which states that product knowledge has a positive and significant influence on consumer attitudes. Subjectively, knowledge of 
product attributes is closely related to self-confidence, confidence, and familiarity with the product. As for objective knowledge, the respondent knows correctly the information about the brand, features, durability, and warranty that the product has. The results of this study are also in accordance with Putri's research (2012) which states that product knowledge has a positive and significant effect on consumer attitudes. Haryanto (2013) in his research on environmentally friendly products found that the intention to buy products can be increased through the development of a positive attitude towards the product. While a positive attitude is enhanced through increasing stimulus that can increase knowledge about the product.

\subsection{Product Knowledge on the Intention of Informal Workers}

Product knowledge has a positive and significant effect on the intention of informal workers to become participants in the BPJS Ketenagakerjaan accepted. That is, the higher the level of knowledge of BPJS Ketenagakerjaan products by informal workers, the higher the intention of informal workers to become participants in the BPJS Ketenagakerjaan, and vice versa. The highest outer loading value of the product knowledge variable is indicated by the place indicator to obtain the product with a value of 0.880 . This shows that the higher the level of knowledge about the place to obtain BPJS Ketenagakerjaan products will affect the intention of the informal workers to become higher participants in the BPJS Ketenagakerjaan.

These results are in accordance with $\mathrm{Li}$ et al. (2002) which states that high knowledge about products will have a positive impact on purchase intention. Knowledge of consumer products will distinguish simple and complex information to determine purchase intentions. Lin and Chen (2006) in their study also found that product knowledge significantly affected consumer buying intentions. Haryanto (2013) in his research on environmentally friendly products found that the intention to buy products can be increased through the development of a positive attitude towards the product. While a positive attitude is enhanced through increasing stimulus that can increase knowledge about the product.

\subsection{Attitudes towards the Intention of Informal Workers}

Attitudes have a positive and significant effect on the intention of informal workers to become participants in the BPJS Ketenagakerjaan accepted. That is, the more positive the attitude of informal workers to BPJS Ketenagakerjaan, the higher the intention of informal workers to become participants in the BPJS Ketenagakerjaan, and vice versa. The highest outer loading value of the attitude variable is shown by the easy access indicator to obtain product information with a value of 0.866 . This shows that the easier the access to obtain information on BPJS Ketenagakerjaan products, the higher the intention of informal workers to become participants in the BPJS Ketenagakerjaan.

These results are in accordance with the results of the Coleman et al. (2011) about the intention to purchase environmentally friendly products, which states that attitude in the form of initiative and commitment influences intention in purchasing products and convenience for consumers is very important. Velasquez (2012) found that the accessibility of a product affects attitudes that influence purchase intention. The attitude of a consumer about the market is a significant extension of TRA. Haryanto (2013) in his research on environmentally friendly products found that the intention to buy products can be increased through the development of a positive attitude towards the product.

\subsection{Subjective Norms for Informal Workers}

Subjective norms have a positive and significant effect on the intention of informal workers to become participants in the BPJS Ketenagakerjaan accepted. That is, the higher the influence of the subjective norms of informal workers, the higher the intention of informal workers to become participants in the BPJS Ketenagakerjaan, and vice versa. The highest outer loading value from the subjective norm variable is indicated by the friend opinion indicator with a value of 0.901 . This shows that the more friends who suggest becoming a BPJS Ketenagakerjaan participant, the higher the intention of informal workers to become participants in the BPJS Ketenagakerjaan.

This result is in accordance with the results of Zhang (2007) 's research which states that intention in purchasing products is influenced by people in the environment around consumers such as families. Budiman and Wijaya (2014) stated that buying intention is influenced by high and low subjective norms, where consumers with low subjective norms have low buying intentions while high subjective norms have high buying intentions. The 
influence of subjective norms can come from groups of people around consumers, both family and friends. Engle et al. (2010) in his research in 12 countries showed that all countries stated that subjective norms were predictors for determining purchase intentions. Consumers will learn a lot from the behavior of others including friends, friends, groups and families. They have the ability to influence through encouragement and support to consumers who think their opinions are important.

\section{Conclusions and Suggestions}

Product knowledge has a positive and significant effect on the attitude of informal workers to BPJS Ketenagakerjaan. Product knowledge has a positive and significant effect on the intention of informal workers to become participants in the BPJS Ketenagakerjaan. Attitudes have a positive and significant effect on the intention to become participants for informal workers. Subjective norms have a positive and significant effect on the intentions of informal workers to become participants in the BPJS Ketenagakerjaan. Product knowledge, attitudes and subjective norms have a positive and significant effect on the intention to become participants.

The surrounding environment such as friends, family, and groups influence the intentions of informal workers to become participants in the BPJS Ketenagakerjaan. This influence is greater than the expression of consumer feelings to provide a consistent response about an object to act on product offerings made by BPJS Ketenagakerjaan. Subjective norms are more likely to influence consumer buying intentions because consumers tend to follow trends. Therefore it is necessary to increase the promotion of BPJS Ketenagakerjaan so that it becomes a trend in the community.

BPJS Ketenagakerjaan must be able to make an effort to improve product knowledge that makes prospective participants consider it important to become a participant in the BPJS Ketenagakerjaan. This can be done by socializing the benefits of the program and the very cheap fees and mutual cooperation principles applied by the BPJS Ketenagakerjaan so that participants who pay the minimum contribution can get the same benefits as participants who pay more contributions.

\section{References}

Budiman, Santi dan Wijaya, T. 2014. Purchase Intention of Counterfeit Products: The Role of Subjective Norm. International Journal of Marketing Studies. Vol.6 No. 2 pp 145-152.

Fu, Frank Q and Michael T. Elliott. 2013. The Moderating Effect Of Perceived Product Innovativeness And Product Knowledge On New Product Adoption: An Integrated Model. Journal of Marketing Theory and Practise. Vol 21 No 3 pp 257-272.

Irandust dan Bamdad. 2014. The Role of Customer's Believability and Attitude in Green Purchase Intention. Kuwait Chapter of Arabian Journal of Business and Management Review. Vol. 3. No. 7 pp 117-135 .

Kotler, Philip dan Kevin Lane Keller. 2009. Marketing Management. Millennium Edition. New Jersey : Prentice Hall International, Inc.

Kotler, Philip dan A.B Suanto. 2009. Manajemen Pemasaran Di Indonesia: Analisis Perencanaan, Implementasi dan Pengendalian. Dialihbahasakan oleh Ancella A. H. Jakarta : Salemba Empat.

Li, Hairong. 2002. Impact of 3-D advertising on product knowledge, brand attitude, and Purchase Intention: The Mediating Role of Presence. Journal of Advertising. Vol 31 No. 3 pp 177-189.

Lin, Long-Yi and Chun-Shuo Chen. 2006. The Influence of The Country-of-Origin Image, Product Knowledge and Product Involvement on Consumer Purchase Decisions: an Empirical Study of Insurance and Catering Services in Taiwan. Journal of Consumer Marketing. Vol. 23. No 5. Pp. 248-265.

Lin, L.-Y. and J.-H Zhen. 2005. Extrinsic Product Performance Signaling, Product Knowledge and Custome Satisfaction: An Integrated Analysis - An Example of Notebook Consumer Behavior in Taipei City. Fu Jen Management Review. Vol. 12 No. 1, pp. 65-91.

Ong, Fon Sim, Kassim, Norison Mohd, Peng, Ooi Shal, and Singh, Taranjeet. 2014. Purchase Behaviour of Consumers of Functional Foods in Malaysia: An Analysis of Selected Demographic Variables, Attitudes and Health Status. Asia Pacific Management Review. Vol. 19 No.1, pp. 81-98.

Peter, J.P. and J.C Olson. 2000. Consumer Behaviour: Perilaku Konsumen dan Strategi Pemasaran. Terjemahan Damos Sihombing. Edisi 4. Jakarta: Erlangga. 
Phau, Ian and Suntornnond, Vasinee. 2006. Dimensions of consumer knowledge and its impacts on country of origin effects among Australian consumers: a case of fast-consuming product. Journal of Consumer Marketing.Vol. 23.No. 1. Pp 34-42.

Salim, A. 2007. Asuransi \& Manajemen Risiko. Jakarta : RajaGrafindo Persada.

Schiffman, L.G and Leslie L. Kanuk. 2007. Consumer Behaviour. New Jersey: Prentice Hall.

Siddiq, Akmal. 2014. Pengaruh Pengetahuan Produk dan Citra Merek Terhadap Keputusan Pembelian Laptop Samsung (Survey pada Konsumen ITKLIK Jakarta). Business and Management Review hal. 1-16.

Suki, Mohd Norazah, T. Ramayah and Norbayah Mohd Suki. 2011. Understanding Consumer Intention with Respect to Purchase and Use of Pirated Software. Information Management \& Computer Security. Vol 19 No 3 pp 195-210.

Tang, Zhongjun, Jianghong Luo, and Juan Xiao. 2011. Antecedents of Intention to Purchase Mass Customized Products. Journal of Product \& Brand Management. Vol 20 No 4 pp 316-326.

Wang, W.-M. 2001. The study of virtual community and experience, internet proficiency, product knowledge and information search cost on consumer perceived risk: an example of PC game soft. Tesis. Chungli : National Central University.

Wu, Chao-Sen. 2015. A Study on Comsumer's Attitude Towards Brand Image, Athletes's Endorsement and Purchase Intention. International Journal of Organizational Innovation. Vol 8 No 2 pp 233-253.

Wulandari, Adisti. A .2009. Pengaruh Sikap dan Norma Subjektif Terhadap Niat Beli Konsumen untuk Sepeda Motor Matik Merek Kymco di Kota Denpasar. Tesis. Denpasar: Universitas Udayana.

Wulandari, Ni Made dan Nurul Hidayah Eko Suwarso. 2015. Pengaruh Pengetahuan dan Sikap terhadap Niat Beli Produk Ramah Lingkungan (Studi kasus pada Pertamax di Kota Denpasar). E-Journal Manajemen Unud. Vol 4 No 10. pp 3119-3145. 